УдК 323.1.316.42

\title{
ОСНОВНІ АСПЕКТИ ЕТНІЧНИХ КОНФЛІКТІВ
}

\section{Лікарчук Наталія Василівна}

доктор політичних наук, професор,

Київський національний університет ім. Тараса Шевченка,

м. Київ, Україна

ORCID: 0000-0001-7119-439X

likarchukd@gmail.com

\section{Лікарчук Дар'я Сергіївна}

кандидат політичних наук,

Київський національний університет культури і мистецтв,

м. Київ, Україна

ORCID: 0000-0003-1603-7601

likarchukd@gmail.com

\section{Шевель Інна Петрівна}

кандидат соціологічних наук, доцент,

Київський національний університет культури і мистецтв,

м. Київ, Україна

ORCID: 0000-0002-6387-2506

shevelinna@ukr.net

Виникнення будь-якого етнополітичного конфлікту обумовлено існуванням тієї чи іншої форми нерівності етносів. Тому врегулювання етнічних конфліктів вимагає знаходження нового, компромісного й прийнятного для всіх конфліктних сторін балансу взаємного задоволення їх інтересів. Проблема етнічних конфліктів протягом останніх десятиліть $\epsilon$ однією з найбільш актуальних тем для дослідників, що представляють різні сфери науки. Головна причина такої пильної уваги до цього питання полягає у важливості розв'язання подібного роду конфліктів, які до того ж стали одним з найбільш поширених джерел суспільних протиріч і політичної нестабільності. Нині на світовій арені присутня наростаюча емоційна напруженість, що супроводжує конфліктні взаємодії, й може спричинити як мобілізуючий, так й дезорганізуючий вплив на поведінку учасників конфлікту. У етнічному

(СЛікарчук Н. В., Лікарчук Д. С., Шевель І. П., 2021 


\section{Міжнародні відносини: теоретико-практичні аспекти \\ Випуск 7 (2021) \\ ISSN (print) 2616-745X; ISSN (online) 2616-7794}

конфлікті, в міру його розвитку, зростає почуття антипатії або ворожості. Приводи й випадки для цього завжди знаходяться.

Події останніх років продемонстрували, що етнічні конфлікти в різних частинах світу виходять за рамки внутрішньодержавних й навіть регіональних. Це має особливе значення у зв'язку з тим, що регіони етнічної нестабільності асоціюються все частіше, й в періодичній, й в науковій літературі, з потенційними суб'єктами міжнародного тероризму. Політико-економічна просторова структуризація полягає в розширенні європейської інтеграції, ускладненні взаємин між політичними акторами, зміні сфер геополітичного впливу, трансформації режимності й демократизації ряду країн. Цей процес досі не завершений повністю, ходячи й підходить до свого логічного фіналу. Запобігання конфліктам можливо тільки при комплексному підході до вирішення проблеми й об’єднанню національною політикою, спрямованою на гармонізацію відносин між різними етносами, а також правоохоронних органів, 3MI.

Ключові слова: конфлікти; етнічні конфлікти; міжнародні відносини; геополітика; етнос; міжетнічні конфлікти.

\section{Вступ}

Етнічні конфлікти в XXI ст. $€$ однією 3 найактуальніших тем для дослідників з різних галузей науки. Ми спостерігаємо нові сплески конфліктів, які грунтуються на соціальних протиріччях й політичній нестабільністі. Аналіз аспектів етнічних конфліктів, їх особливості, характеристики розкривають можливості для формування нових механізмів та способів розв'язання конфліктів. Етнічні конфлікти, у певній мірі, - це стихійні соціальні порушення, що мають глобальні наслідки.

У кожна конфліктній ситуації, що пов'язано з етнічністю (учасники конфлікту створюють таку ситуацію), поняття «етнічність» плавно переходить в термін «міжетнічний конфлікт», відбувається конкретизація учасників та їх приналежність до тих чи інших спільнот. Тому значення терміна «конфлікт» пов'язане з етнічним фактором.

У цілому виникнення будь-якого етнополітичного конфлікту обумовлено існуванням тієї чи іншої форми нерівності етносів. Тому врегулювання етнічних конфліктів вимагає знаходження нового, компромісного й прийнятного для всіх конфліктних сторін балансу взаємного задовольняють їх інтересів. 
Хоча в розвитку етнополітичних конфліктів відбувається багато однотипних процесів, в кожному з конфліктів беруть участь люди зі своїми уявленнями й переконаннями. Атмосфера сильної напруги призводить до того, що поведінка людей в конфліктних ситуаціях часто не піддається логічному аналізу, не грунтується на здоровому глузді. Тому ймовірність знайти рішення конфліктної проблеми, яке в повній мірі задовольнило б конфліктуючі сторони, дуже мала. У кращому випадку сторони приймають компромісне рішення, яке не дозволяє врегулювати конфлікт по суті, остаточно, а переводить його в латентний стан. При цьому немає ніяких гарантій, що наступні покоління конфліктуючих спільнот будуть задоволені подібним рішенням й не відновлять відкритий конфлікт.

Науковці описують конфлікт як систему перемінних, де сама переміна становить домінування і розбіжності, які і визначають конфлікт етнічного, який має різні форми, такі як від латентного до чітко втраженного виду конфлікту.

\section{Аналіз останніх досліджень і публікацій}

Вивченням проблеми врегулювання етнополітичних конфліктів займалося багато вчених, зокрема: С. Вольф, Г. Гейл, А. Кіссе, С. Корнел, Дж. МакГаррі, Дж. Ротшильд, С. Сайдеман, У. Шнекенер.

В українській науці окремим аспектам даної проблематики присвячені праці таких науковців як О. Картунової, І. Кресіної, О. Кривицької, М. Пірен, В. Ребкала, Ю. Римаренка, Г. Перепелиці, В. Євтух, М. Пірен та ін.

Незважаючи на значну кількість наукових досліджень, присвячених проблемі ектнічних конфліктів, варто формувати нові механізми їх розв'язання, адже конфлікти $\epsilon$ мінливими й часто з латентної фази переходять у відкриту.

\section{Формулювання цілей статті}

Дослідити стан, проблеми й перспективи вивчення етнічних конфліктів в Європі, з'ясувати їх сутності, передумови й причин виникнення, розкрити механізми й способи їх розв'язання.

\section{Виклад основного матеріалу дослідження}

Проблема етнічних конфліктів протягом останніх десятиліть є однією 3 найбільш актуальних тем для дослідників, що представляють різні сфери науки. Головна причина такої пильної уваги до цього питання полягає в важливості розв'язання подібного роду конфліктів, які до того ж стали одним 3 найбільш поширених джерел суспільних протиріч та політичної нестабільності.

(СЛікарчук Н. В., Лікарчук Д. С., Шевель І. П., 2021 


\section{Міжнародні відносини: теоретико-практичні аспекти \\ Випуск 7 (2021) \\ ISSN (print) 2616-745X; ISSN (online) 2616-7794}

Події останніх років продемонстрували, що етнічні конфлікти в різних частинах світу виходять за рамки внутрішньодержавних і навіть регіональних. Це має особливе значення у зв'язку з тим, що регіони етнічної нестабільності асоціюються все частіше, й в періодичній, й в науковій літературі, з потенційними суб'єктами міжнародного тероризму.

У свій час політолог Д. С. Лікарчук, відзначила, що «Безперервні війни, революції, конфлікти, соціальні й економічні потрясіння становлять паралель перманентного процесу, пошуку можливостей перервати дану тенденцію знайти механізм вилучення з життя людей найгостріших форм соціальнополітичної конфронтації» (Likarchuk, 2020a, p. 35).

Згідно 3 класичним визначенням, етнополітичний конфлікт - це здійснюване в тій чи іншій формі групове протиборство, що має політичну мету, й коли хоча б одна зі сторін апелює до етнічності (Ciccone, 2011).

Серед найбільш відомих теорій етнічних конфліктів комплексного характеру слід виділити теорії Джозефа Ротшильда, Дональда Горовіца, Теда Гурра, Гюнтера Шлее.

Гюнтер Шлее, в своїх роботах про етнополітичні конфлікти посилається на приклад Югославії. Вважається, що югославська криза - приклад класичного етнополітичного конфлікту сучасності. У зв'язку з цим найбільш показовою $\epsilon$ ситуація в Боснії, яку Гюнтер Шлее називає «Югославією в мініатюрі» (Schlee, 2004 , р.137). Дослідження передвоєнного часу показували, що відбувалося поступове зникнення «югославянскої етнічності» й розпочався процес формування єдиного югославського народу. У різних частинах країни цей процес протікав з різною інтенсивністю, але він був очевидний.

У Боснії переважна частина населення аж до 1990-х рр. не надавала істотного значення етнічному чиннику. По суті, етнічність була нав'язана місцевим сербам, хорватам й мусульманам зусиллями політиків, й уявні культурні відмінності стали реальною підставою не тільки для поділу громад, а й для їх жорстокого протистояння (Schlee, 2004, p. 141).

Криза, на поч. 90-х рр. XX ст., не закінчилася підписанням Дейтонських угод. Також загострення ситуації в Автономному краї Косово й Метохії призвело до нового витка кризи, на врегулювання якого були спрямовані зусилля міжнародних організацій та світової дипломатії, що в кінцевому підсумку призвело до самопроголошеної Республіки Косово (Schlee, 2004, p. 142).

Гюнтер Шлее відзначив, що основоположними причинами сучасних етнополітичних конфліктів $є$ відмінності в розумінні природи сучасних націй. Концепція «нації-етносу» послужила основою: ідеї Eretz Israel й концепту 
«Великої Сербії», етнічного націоналізму Буміпутра в Малайзії, амхара в Ефіопії, що поризвело до протиріч й конфліктів (Schlee, 2004, p. 145).

У теорії етнічної стратифікації Джозефа Ротшильда, вперше запропоновано розглядати етнічні групи як суб'єкти етнополітичного конфлікту, приділяючи при цьому серйозну увагу аналізу як ресурсного потенціалу сторін, так і можливостей політичної мобілізації групи (Rothschild, 1983, p. 1317). На думку вченого, успіхи й активність етнополітичних рухів залежать від економічних, політичних та ідеологічних ресурсів, якими може оперувати група. Крім того, необхідно враховувати склад групи, її соціальні та культурні характеристики.

При проведенні порівняльного аналізу конфліктів у сучасній Європі вдалося виявити деякі закономірності розвитку конфліктних відносин. По-перше, навіть в умовах стабільного політичного розвитку й застосування ефективних та адекватних технологій етнічні, конфлікти можуть бути тільки частково врегульовані, але не повністю завершені. По-друге, наявність досвіду політичного врегулювання конфліктів, а також наявність демократичних принципів в політичній культурі населення $\epsilon$ гарантами мирного й не насильницького вирішення етнічних конфліктів навіть в умовах краху політичної системи держави. По-третє, інтеграція Європи в єдиний європейський простір, фактично мінімізує значимість державних кордонів, у тому числі й для формування та розвитку етнічності, але це не означає припинення міжетнічних протиріч, а значить, не забезпечує запобігання конфліктів з етнічною складовою (Esteban, Debraj, 2011).

Кількість, роль й значення етнополітичних конфліктів, в сучасному світі, змінні, але практично не зменшуються, а час їх протікання подовжується, що викликано:

- глобалізацією, знижується роль національних держав й підвищує значення регіонів;

- переходом від світових конфліктів до регіональних;

- різким збільшенням доступності інформації;

- зіткненням формувань інформаційної свідомості;

- свідомістю архаїчною, доіндустріальною (Esteban, Debraj, 2011).

Варто відзначити, що навіть провідні фахівці-транзитології, мало уваги приділяють істотних відмінностей, які склалися між країнами ЦентральноСхідної Європи та країнами колишнього Радянського Союзу. Серед країн Центрально-Східної Європи переважають нові ліберальні представницькі демократії, гібридні режими характерні для невеликої кількості країн:

(С Лікарчук Н. В., Лікарчук Д. С., Шевель І. П., 2021 


\section{Міжнародні відносини: теоретико-практичні аспекти \\ Випуск 7 (2021) \\ ISSN (print) 2616-745X; ISSN (online) 2616-7794}

Албанії, Боснії, Сербії, Чорногорії, Македонії. Серед країн колишнього Радянського Союзу лише Латвія, Литва й Естонія можуть бути віднесені до консолідованих демократій, для всіх інших країн характерні гібридні або автократичні режими (Schlee, 2004, p. 147).

Як відзначають науковці (Esteban, Debraj, 2011), то країни Європи, розподілені на «зони» етнополітичних конфліктів.

«Перша зона» - це територія Центральної Європи. Усі етнополітичні конфлікти тут пов'язані з розпадом Югославії й Албанією. За певних обставин, описаних вище, сюди можна віднести й конфлікт в Боснії і Герцеговині (1992).

«Друга зона» - це російська зовніщня політика, що включає Україну, Білорусь, Грузію. Тут можна виділити Придністровський конфлікт.

«Третя зона» - збройний конфлікт на території Північного Кавказу (2009-2017). Існує низка дискусій про європейську приналежність Кавказу, але в геополітичному сенсі - це Європа.

«Четверта зона» - це територія Південного Кавказу. Азербайджан, Вірменія, Грузія - залучені в збройні етнополітичні конфлікти (Esteban, Debraj, 2011).

Етнічні конфлікти $€$ тим феноменом, який значною мірою змінив світовій комунікативний простір. Подібні протистояння стали інструментом просторової структуризації. На зміну «генетики посткомунізму» поступово приходить процес регіоналізації європейської периферії (Esteban, Debraj, 2011). Центральна й Східна Європа - це великий за масштабами регіон, який поступово об’єднується в рамках Європейського Союзу. Однак ряд країн цього регіону мають лише віддалені перспективи входження в інтегровану Європу.

У цьому випадку варто відзначити, точку зору українських науковців в питаннях конфлікту й фаворитизму: «Фаворитизм $є$ найпоширенішим джерелом конфлікту вбудь-якій структурі, а точніше - одним із його різновидів - конфлікту інтересів» (Likarchuk, 2020b, p. 20). Така система відображається й в етнічних конфлікиах, коли кожна строна показує свою перевагу над іншою.

Відповідно до вище відзначеного, дослідники виділяють «раціональний» й «деструктивний» конфлікти (Mack, 2002, p. 517). Сторони «раціонального» конфлікту готові визнати обгрунтованість вимог конфліктуючих суб'єктів й намагаються врегулювати ентічний конфлікт. Однак «раціональні» конфлікти становлять меншу частину етнополітичних зіткнень, й прикладом їх успішного вирішення можна назвати мирний вихід Норвегії зі складу Шведського королівства або розділ Чехословаччини на Чехію й Словаччину. 
Розглядаючи механізми врегулювання етнополітичних конфліктів, директор проєкту із систем переговорів при Школі права Гарвардського університету Уїльям Юрі прийшов до висновку, що «Збільшення числа етнічних конфліктів стало результатом широкого явища - передачі владних повноважень на нижчий політичний рівень» (Ury, 1999). Він зазначає, що всі етнічні групи у світі в своєму розвитку проходять три етапи:

1) етап залежності й дискримінації;

2) етап незалежності;

3) етап взаємозалежності або взаємовигідного співіснування з іншими групами (Ury, 1999).

Нині на світовій арені присутня наростаюча емоційна напруженість, що супроводжує конфліктні взаємодії, й може спричинити як мобілізуючий, так й дезорганізуючий вплив на поведінку учасників конфлікту. У етнічному конфлікті, в міру його розвитку, зростає почуття антипатії або ворожості. Приводи й випадки для цього завжди знаходяться.

Для етнічного конфлікту характерне формування стійкого образу «зовнішнього ворога», коли компроміс сприймається тільки як капітуляція супротивника, коли прагнення кожної зі сторін учасниць протиборства «здобути перемогу» (Esteban, Debraj, 2011). Показовими в цьому відношенні $\epsilon$ Придністров'я, Грузія, Карабах, де пошуки компромісу, мирних рішень не були дієвими.

Слід відзначити, що політико-економічна просторова структуризація полягає в розширенні європейської інтеграції, ускладненні взаємин між політичними акторами, зміні сфер геополітичного впливу, трансформації режимності й демократизації ряду країн. Цей процес досі не завершений повністю, ходячи й підходить до свого логічного фіналу.

С. Олзак й Дж. Нейджл виокремили декілька моментів впливу соціальноекономічних змін у суспільстві на процеси етнополітичної мобільності в Європі:

- урбанізація соціальної діяльності, яка загострює конкуренцію між представниками різних етнічних груп, що переселяються в міста з районів попереднього проживання;

- індустріалізація, яка також може розширити етнічну конкуренцію за робочі місця;

- економічний розвиток периферійних районів або відкриття нових стратегічних ресурсів економічного росту на периферії, зайнятих компактними етнічними популяціями, які, як правило, створюють потенціал для руху -

(С) Лікарчук Н. В., Лікарчук Д. С., Шевель І. П., 2021 


\section{Міжнародні відносини: теоретико-практичні аспекти \\ Випуск 7 (2021) \\ ISSN (print) 2616-745X; ISSN (online) 2616-7794}

оновлення етнічних політичних партій та рухів, що часто обертається конфліктом (Olzak, Nagel, 1986, p. 13).

Европейські експерти, відзначають, що етнополітичні конфлікти не $є$ лише конфліктами економічних інтересів, а є конфліктами ідентичності, адже участь у конфлікті відбувається переважно на основі групових мотивів й обов'язково передбачає ставлення людини як актора етнічної ідентифікації.

Виділяють основні механізми запобігання етнічних конфліктів:

- застосування механізмів (за допомогою зміни законодавства, соціальної структури, введення санкцій);

- переговори, де відбувається посередництво при проведенні переговорів з суб'єктами конфліктів (у розвинених країнах такі переговори здійснюються медіаторами);

- інформаційний шлях, який передбачає взаємний обмін інформацією між групами при дотриманні умов, що сприяють зміні ситуації (Olzak, Nagel, 1986, p. 14).

Як відзначає український соціолог І. П. Шевель: «...саме толерантність відіграє важливу роль у складній сучасній ситуації для побудови взаємовідносин і взаємодій як у межах країни, так і за її межами» (Shevel, 2020, p. 277).

Будь-який конфлікт, будь то етнічний чи міжетнічний відбувається завдяки багатьом факторам. Класифікація цих конфліктів здійснюється не зважаючи на те, «що» чи «хто» ним генерує. Це корелюється в будь-яких сферах етнічних груп у розвитку суспільства. Причини, які є збудником конфлікту між собою постійно взаємодіють і мають етнічну мотивацію.

Наше українське суспільство є поліетнічною державою і міжетнічний конфлікт є одним з ї̈ елементів і виступає джерелом конфлікту. В етнічній спільноті конфлікт виникає на основі соціально-економічної нерівності та культурна занедбаності. В Україні проживає близько 130 етносів і вони між собою тримають етнічну дистанцію в межах парадигми відносин «ми - вони». Ці риси для них є основними, щоб порівнювати себе з іншими. Як ми можемо проаналізувати дані соціологічного дослідження, яке проводилося методом спостереження, що відмінності проявляються в культурі в першу чергу і це підкреслюється в етнічній ідентичності, наприклад, українці відрізняються від грузинів, англійці від французів передусім у культурі. Активне порівнювання себе з іншими у міжетнічній взаємодії призводить до потенційного майбутнього конфлікту завдяки етнічному дистанціюванню, тобто змаганню. 
На початку міжетнічного конфлікту може виникати етнічна неприязнь. Несприйняття людей 3 іншої культури через етнічні негативні стереотии розглядаються науковцями як абсурдна поведінка через нестачу інформації про той чи інший етнос чи націю із ЗMI, літератури, історичних джерел.

Після етнічної неприязні настає етнічна ворожість, негативне ставлення до визначених етнічних спільнот. В Україні фіксуються випадки ворожості щодо євреїв, кримських татар, до африканців, арабів. У країнах Західної Європи 2005-2006 рр. рівень етнічної ворожості щодо мусульманських країн значно зріс, перш за все, соціальних і політичних.

Прояви міжетнічної напруги аналізовувався у співвідношенні «більшість - меншість». Міжетнічна солідарність не прослідковується. Нинішня етнополітична ситуація в Україні, може показати прояв етнічної напруги. Коли одна етнічна спільнота прагне поліпшити свій соціальний статус і роль в культурному житті суспільства, то інші представники спільноти не приймають участі в цьому.

Етнічна конфронтація, яка реалізується у протиставленні інтересів однієї етнічної спільноти інтересам іншої і виникає міжетнічний конфлікт, який носить переважно керований характер з боку лідерів етнічних груп.

Етнічний антагонізм є пікова точка етнічної напруги і конфронтації, де відбуваються жорсткі змагання за місце в поліетнічній країні і завершує формування структури міжетнічного конфлікту (Yevtukh, 2006, p. 3-17).

У кожному конфлікті і в міжетнічному не виняток, велику роль виконують актори конфлікту. До них ми можемо віднести, по-перше, учасника конфлікту; по-друге, суб'єкта конфлікту; по третє, посередника у конфлікті. Усі актори пов'язані певним контекстом, їхніми відносинами та самим конфліктом між ними. Феномен «міжетнічний конфлікт» не може трактуватися лише поняттям як «сторона конфлікту» в порівнянні до його учасників. Подібні ситуації спостерігаються на Північному Кавказі, в Ізраїлі, де перебіг конфлікту супроводжується суб'єктами конфлікту та їх інтересами, де суб’єктами можуть бути різні представники влади, партій, організацій і т. д. Усі дослідники знають, що роль посередника в будь-якому конфлікті відіграє важливу роль в управлінні конфліктом і виконують функцію примирення.

У міжетнічному конфлікті політичні причини пов'язані створити свої етнополітичні організми (ЕПО) (Yevtukh, Troshchynskyi, Halushko, et al., 2003, p. 219), чи етносоціальні організми (ECO) (Yevtukh, Troshchynskyi, Halushko, et al., 2003, p. 219), для доступу прийняття рішень, які впливають на їх статус та етнонаціональний розвиток політичної країни. Конфлікт виникає у випадку

(С) Лікарчук Н. В., Лікарчук Д. С., Шевель І. П., 2021 


\section{Міжнародні відносини: теоретико-практичні аспекти \\ Випуск 7 (2021) \\ ISSN (print) 2616-745X; ISSN (online) 2616-7794}

прагнення етнічних спільнот зміцнити свій статус в етнокультурному просторі поліетнічної країни та для збереження своєї ідентичності.

Міжетнічні конфлікти проявляються на двох стадіях: «більшість меншість»; «меншість - меншість». До таких, належить, скажімо приклад, того що на початку масових міграцій до США і Канади (кін. XIX-XX ст.) було схвалено закон, щоб врегульовувати міграційні потоки прибулих у нові суспільства. Але ці закони принаймні спрацьовували лише короткий час і не приносили цим державам «незручностей».

Формувалися концепції етнонаціонального розвитку США і Канади y XIX-XX ст., які забезпечували адаптацію та інтеграцію нових іммігрантів та етнічних спільнот, які довго проживали на території цих країн, їх поведінка напрявлялася на безконфліктну інтеграцію у суспільство проживання. Ці концепції затверджувались на урядовому рівні урядів США і Канади з боку етнічного та національного розвитку. Вони складаються з «англоконформізму», «культурного плюралізму», «полікультурності», «етнічності» (Yevtuh, 1991, p. 8-24).

\section{Висновки}

Аналізуючи вищесказне, що феномен етнічних та етнополітичних конфліктів відтворює його основу і регулює їх ситуації, які виникають у прояві їх функціонування.

Етнічний конфлікт $€$ складним й неоднозначним явищем, яке складається з багатьох основ, кожна з яких в різній мірі впливає на зіткнення між етносами.

Запобігання конфліктам можливо тільки при комплексному підході до вирішення проблеми й об'єднанню національною політикою, спрямованою на гармонізацію відносин між різними етносами, а також правоохоронних органів, 3МI.

В аналітичному плані етнополітичні конфлікти необхідно розглядати в контексті етнізації політики та політизації етнічності. Особливістю сучасних етнополітологічних досліджень $є$ підвищена увага до соціокультурних, ціннісних компонентів етнополітичних конфліктів. Часто відбувається трансформація етнополітичного конфлікту в конфлікт ідентичності й означає розширення бази та ускладнення шляхів його врегулювання. 


\section{References:}

1. Ciccone, A. (2011). 'Economic Shocks and Civil Conflict: A Comment'. American Economic Journal: Applied Economics, Vol. 3, no.4, pp.215-227. DOI: [10.1257/app.3.4.215.

2. Esteban, J., Debraj, R. (2011). 'A Model of Ethnic Conict'. Journal of the European Economic Association, Vol. 9, no. 3, pp.496-521. DOI: 10.1111/j.15424774.2010.01016.x.

3. Evtukh, V. B. (1991). Kontseptsiya etnosotsial'nogo razvitiya SShA i Kanady: tipologiya, traditsii, evolyutsiya [Concepts of ethnosocial development of the USA and Canada: typology, traditions, evolution]. Kyiv: Naukova Dumka.

4. Likarchuk, D. (2020). 'Rol mizhnarodnykh orhanizatsii u vrehuliuvanni zovnishnopolitychnykh konfliktiv' [The role of international organisations in the settlement of foreign policy conflict]. Mizhnarodni vidnosyny: teoretyko-praktychni aspekty [International Relations: Theory and Practical Aspects], issue 5, pp. 35-44. DOI: $10.31866 / 2616-745 \times .5 .2020 .203663$.

5. Likarchuk, N. (2020). 'Favoritism as a Manifestation of Corruption and Managerial Incompetence'. Bulletin of Taras Shevchenko National University of Kyiv. Public Administration, Vol. 11, no. 1, pp. 17-22. DOI: 10.17721/2616-9193.2019/11$2 / 7$.

6. Mack, A. (2002). 'Civil War: Academic Research and the Policy Community'. Journal of Peace Research, Vol. 39 , no. 5, pp. 515-525.

7. Maiboroda, O., Chilachava, R., Pylypenko T., et al. (2002). Spryiannia poshyrenniu tolerantnosti u polietnichnomu suspilstvi [Promoting tolerance in a polyethnic society]. Kyiv: Fond Yevropa XXI, pp. 182-210.

8. Olzak, S., Nagel, J. (1986). 'Introduction. Competitive Ethnic Relations: An Overview'. Competitive Ethnic Relations. Orlando: Academic Press, pp. 1-16.

9. Rothschild, J. (1983). 'Ethnopolitics: A Conceptual Framework'. American Journal of Sociology, Vol. 88, no. 6, pp. 1317-1319.

10. Schlee, G. (2004). 'Taking sides and constructing identities: reflections on conflict theory'. Journal of the Royal Anthropological Institute, Vol. 10, no. 1, pp. 135156.

11. Shevel, I. (2020). ' Sotsialni napruzhennia v kulturnii sferi: istoriia, suchasnyi stan ta transkulturni vplyvy' [Social struggles in the cultural sphere: history, modern state, and transcultural influence]. Mizhnarodni vidnosyny: teoretykopraktychni aspekty [International Relations: Theory and Practical Aspects], issue 5, pp. 276-285. DOI: 10.31866/2616-745x.5.2020.203723.

(СЛікарчук Н. В., Лікарчук Д. С., Шевель І. П., 2021 
12. Ury, W. (1999). Getting to Peace: Transforming Conflict at Home, at Work, and in the World. New York: Viking.

13. Yevtukh, V. (2006). Sociology of interethnic conflict: theoretical aspect. Political Manager. Vol.6. pp. 3-17.

14. Yevtukh, V.B., Troshchynskyi, V.P., Halushko, K. Yu., et al. (2003). Etnosotsiolohiia. Terminy ta poniattia [Ethnosociology. Terms and concepts.]. Kyiv: Vydavnytstvo UANNP “Feniks”, pp. 162-174. 


\section{MAIN ASPECTS OF ETHNIC CONFLICTS}

\section{Likarchuk Natalia}

Doctor of Political Sciences, Professor,

Kyiv National Taras Shevchenko University,

Kyiv, Ukraine

ORCID: 0000-0001-7119-439X

likarchukd@gmail.com

\section{Likarchuk Daria}

Candidate of Political Science,

Kyiv National University of Culture and Arts,

Kyiv, Ukraine

ORCID: 0000-0003-1603-7601

likarchukd@gmail.com

\section{Shevel Inna}

Candidate of Sociological Sciences, Associate Professor,

Kyiv National University of Culture and Arts,

Kyiv, Ukraine

ORCID: 0000-0002-6387-2506

shevelinna@ukr.net

The emergence of any ethno-political conflict is caused by the existence of one or another form of ethnic inequality. Therefore, the settlement of ethnic conflicts requires finding a new, compromise and acceptable for all parties to the conflict balance of mutual satisfaction of their interests. In recent decades, the problem of ethnic conflicts has been one of the most relevant topics for researchers representing various fields of science. The main reason for such a close attention to this issue is the importance of resolving such conflicts, which have also become one of the most common sources of social controversy and political instability. Today, there is a growing emotional tension on the world stage that accompanies conflict interactions and can have both mobilizing and disorganizing effects on the behaviour of conflict participants. In ethnic conflict, as it is developing, the feeling of antipathy or hostility increases. There are always reasons and cases for this.

(С) Лікарчук Н. В., Лікарчук Д. С., Шевель І. П., 2021 
Recent events have shown that ethnic conflicts in different parts of the world go beyond domestic and even regional ones. This is especially important due to the fact that regions of ethnic instability are increasingly associated, both in periodicals and in the scientific literature, with potential subjects of international terrorism. Political and economic spatial structuring consists in the expansion of European integration, the complication of relations between political actors, the change of spheres of geopolitical influence, the transformation of the regime and the democratization of a number of countries. This process is not yet complete, walking and approaching its logical end. Conflict prevention is possible only with a comprehensive approach to solving the problem and combining national policies aimed at harmonizing relations between different ethnic groups, as well as law enforcement agencies and the media.

Key words: conflicts; ethnic conflicts; international relations; geopolitics; ethnicity; interethnic conflicts. 


\title{
ОСНОВНЫЕ АСПЕКТЫ ЭТНИЧЕСКИХ КОНФЛИКТОВ
}

\author{
Ликарчук Наталья Васильевна \\ доктор политических наук, професор, \\ Киевский национальный університет им. Тараса Шевченко, \\ 2. Киев, Украина \\ ORCID: 0000-0001-7119-439X \\ likarchukd@gmail.com
}

\section{Ликарчук Дарья Сергеевна}

кандидат политических наук,

Киевский национальный университет культуры и искусств,

2. Киев, Украина

ORCID: 0000-0003-1603-7601

likarchukd@gmail.com

\section{Шевель Инна Петровна}

кандидат социологических наук, доцент,

Киевский национальный университет культуры и искусств,

2. Киев, Украина

ORCID: 0000-0002-6387-2506

shevelinna@ukr.net

Возникновение любого этнополитического конфликта связано с существованием той или иной формы этнического неравенства. Следовательно, урегулирование межнациональных конфликтов требует поиска нового, компромиссного и приемлемого для всех сторон конфликта баланса взаимного удовлетворения их интересов. Проблема межнациональных конфликтов в последние десятилетия - одна из самых актуальных тем для исследователей, представляющих различные области науки. Основная причина такого пристального внимания к этому вопросу - важность разрешения подобных конфликтов, которые также стали одним из самых распространенных источников социальных противоречий и политической нестабильности. Сегодня на мировой арене растет эмоциональное напряжение, которое сопровождает конфликтные взаимодействия и может оказывать как мобилизующее, так и дезорганизующее воздействие на поведение участников

(С) Лікарчук Н. В., Лікарчук Д. С., Шевель І. П., 2021 


\section{Міжнародні відносини: теоретико-практичні аспекти \\ Випуск 7 (2021) \\ ISSN (print) 2616-745X; ISSN (online) 2616-7794}

конфликта. В этническом конфликте по мере его развития нарастает чувство антипатии или враждебности. Для этого всегда есть причины и случаи.

Последние события показали, что этнические конфликты в разных частях света выходят за рамки бытовых и даже региональных. Это особенно важно в связи с тем, что регионы этнической нестабильности все чаще ассоциируются как в периодических изданиях, так и в научной литературе с потенциальными субъектами международного терроризма. Политическое и экономическое пространственное структурирование заключается в расширении европейской интеграции, усложнении отношений между политическими акторами, изменении сфер геополитического влияния, трансформации режима и демократизации ряда стран. Этот процесс еще не завершен, идет и приближается к своему логическому завершению. Предотвращение конфликтов возможно только при комплексном подходе к решению проблемы и сочетании национальной политики, направленной на гармонизацию отношений между разными этническими группами, а также правоохранительными органами и СМИ.

Ключевые слова: конфликты; этнические конфликты; международные отношения; геополітика; этничность; межэтнические конфликты. 